\title{
Biological Activity of Porcine Gastric Mucin on Stress Resistance and Immunomodulation
}

\author{
Thiloma D. Liyanage ${ }^{1}{ }^{1}$, Pasan S. Dahanayake ${ }^{2}{ }^{\oplus}$, Shan L. Edirisinghe ${ }^{1}(\mathbb{D}$, \\ Chamilani Nikapitiya ${ }^{1}$, Gang-Joon Heo ${ }^{2}$, Mahanama De Zoysa ${ }^{1, * \mathbb{D}}$ and Ilson Whang ${ }^{3, * \mathbb{C}}$ \\ 1 College of Veterinary Medicine, Chungnam National University, Yuseong-gu, Daejeon 34134, Korea; \\ thilomaliyanage@gmail.com (T.D.L.); shan.lakmal09011@gmail.com (S.L.E.); chamilani14@gmail.com (C.N.) \\ 2 College of Veterinary Medicine, Chungbuk National University, Cheongju 28644, Korea; \\ pasansd@gmail.com (P.S.D.); gjheo@cbu.ac.kr (G.-J.H.) \\ 3 National Marine Biodiversity Institute of Korea (MABIK), 75, Jangsan-ro 101beon-gil, Janghang-eup, \\ Seochun-gun, Chungchungnam-do 33662, Korea \\ * Correspondence: mahanama@cnu.ac.kr (M.D.Z.); ilsonwhang@mabik.re.kr (I.W.)
}

Received: 29 May 2020; Accepted: 25 June 2020; Published: 29 June 2020

\begin{abstract}
Purified porcine gastric mucin (PGM) is an alternative biomaterial to native mucin which displays multifunctional properties for exploring a wide range of biomedical applications. The present study evaluated the in vitro (RAW 264.7 macrophage cells) and in vivo (zebrafish embryos and larvae) bioactivities of PGM. The median lethal concentration ( $\mathrm{LC}_{50}$ ) of PGM was $197.9 \mu \mathrm{g} / \mathrm{mL}$ for embryos, while it was non-toxic to RAW 264.7 cells, even at $500 \mu \mathrm{g} / \mathrm{mL}$. Following PGM exposure (100 $\mu \mathrm{g} / \mathrm{mL})$, a higher embryo hatching rate (59.9\%) was observed at $48 \mathrm{~h}$ post fertilization, compared to the control (30.6\%). Protective effects of PGM from pathogenic Aeromonas hydrophila were demonstrated by high larvae survival rates of $85.0 \%$ and $94.0 \%$ at 50 and $100 \mu \mathrm{g} / \mathrm{mL}$ of PGM exposure, respectively. Heat tolerance effect of PGM ( 50 and $100 \mu \mathrm{g} / \mathrm{mL}$ ) on larvae $\left(40{ }^{\circ} \mathrm{C}\right.$ for $48 \mathrm{~h}$ ) was confirmed by $75 \%$ and $100 \%$ of survival rates, respectively. Additionally, PGM reduced the A. hydrophila-induced reactive oxygen species (ROS) generation in larvae. The qRT-PCR results in PGM exposed larvae exhibited induction of immune-related genes (tlr $5 a$ and $t l r 5 b, m y d 88, c-r e l, i l 1 \beta, t n f-\alpha, i l 6, i l 10, c x c l 18 b$, ccl34a.4, defbl1, hamp, ctsd, muc2.1, muc5.1, muc5.2, and muc5.3), stress response (hsp70, hsp90aa1.1, and hsp90ab1), and antioxidant genes (cat and sod1). Moreover, our results revealed that PGM involved in the regulation of transcriptional gene induction increases Hsp90 protein in the zebrafish larvae. Furthermore, upregulation of Il6, Il10, Tnfo, Ccl3, Defa-rs2, Defa21 and Camp and antioxidant genes (Sod2 and Cat) were observed in PGM-exposed RAW 264.7 cells. Overall findings confirmed the activation of immune responses, disease resistance against pathogenic bacteria, heat tolerance, and ROS-scavenging properties by PGM, which may provide insights into new applications for PGM as a multifunctional immunomodulator.
\end{abstract}

Keywords: disease resistance; heat tolerance; immunomodulation; mucin; oxidative stress; zebrafish

\section{Introduction}

Globally, various approaches have been introduced to prevent and control diseases in aquaculture. The use of immunostimulants is a promising and environmentally friendly method to enhance the innate defense mechanisms of fish [1]. In general, immunostimulants consist of biological and synthetic compounds that trigger relevant components of the immune system, to confer protection against specific pathogens. They help to boost the development and strengthen the disease resistance of fish, and these impacts are dependent on the structure and function of different immunostimulants [2]. 
Mucins are high-molecular-weight glycoproteins produced by a wide range of epithelial tissues in animals. They are composed of a protein backbone that consists of tandem repeats of threonine-and serine-rich amino acid residues, and a large number of $O$-linked carbohydrate side chains [3-7]. Mucins are divided into two groups (secreted and membrane-bound), based on their structure, function, and subcellular localization [8-11]. The presence of alternating arrays of hydrophilic glycosylated regions and hydrophobic unglycosylated regions ensures the amphiphilic character of mucin [12]. Mucins play a critical role in forming the protective barrier of mucous membranes. In addition, they have several specific functions, including solute transport regulation, establishment of binding sites for commensal and pathogenic microbes, and leukocyte targeting. Moreover, they are known to regulate cellular regeneration, integration, differentiation, cell signaling, cell adhesion, and apoptosis [7,13-15].

Native mucins have shown excellent surface adsorption and lubrication properties, which has a potential impact on biomedical applications [16]. Several in vivo infection studies in aquaculture have demonstrated the role of mucins and mucin glycosylation in the defense against fish pathogens [17-19]. Similarly, porcine gastric mucin (PGM) has been used as an alternative for native mucin to understand host-pathogen interactions $[16,20]$. Moreover, PGM has been used in a wide range of supplements, personal hygiene products, and lubricants, as well as in artificial saliva, due to its promising antiviral activity, biocompatibility, and availability [21]. However, studies have also reported cell toxicity effects during cell culture experiments, and inferior effects on virus inhibition upon reconstituted commercial mucin treatments [16,21].

To the best of our knowledge, there has been no study to date that explores the effect of exogenous PGM as a modulator of innate immune responses. The present study focused to understand the immunomodulatory effects of PGM by conducting in vitro assays, using RAW 264.7 macrophage cells and zebrafish (Danio rerio), as an appropriate in vivo model. Thereby, we investigated PGM effect on hatching percentage (\%), reactive oxygen species (ROS) scavenging properties, disease resistance, thermal (heat) tolerance and immune-modulation upon exposure in zebrafish larvae, and RAW 264.7 cells.

\section{Results}

\subsection{The In Vivo and In Vitro Toxic Effects of PGM}

PGM was completely dissolved in distilled water, without any precipitation, at $4 \mathrm{mg} / \mathrm{mL}$ of final concentration. The solution of PGM had a slightly basic $\mathrm{pH}$ of 7.1 at $25^{\circ} \mathrm{C}$ (Figure 1A). When zebrafish embryos were exposed to PGM $(50,100,200$, and $400 \mu \mathrm{g} / \mathrm{mL})$, acute mortality was observed only in higher concentrations ( $>200 \mu \mathrm{g} / \mathrm{mL}$ ) of PGM, at $24 \mathrm{~h}$ post exposure (hpe). In contrast, PGM-treated embryos at lower concentrations (50 and $100 \mu \mathrm{g} / \mathrm{mL}$ ), as well as untreated embryos (control group), had zero mortality throughout the 96 hpe (Figure 1B). The outcome of toxicity results revealed that the zebrafish embryos were least sensitive with median lethal concentration $\left(\mathrm{LC}_{50}\right)$ of $197.9 \mu \mathrm{g} / \mathrm{mL}$ at 96 hpe. Figure 1C2-C3' depicts the deformities caused by PGM exposure at higher concentrations (200 and $400 \mu \mathrm{g} / \mathrm{mL}$ ). Deformities such as spinal curvature (Figure 1C2,C3'), pericardial edema (Figure 1C3), head deformities, and underdeveloped embryos were observed (Figure 1C3,C3'). The typical appearance of larvae without deformities was observed in the untreated control group (Figure 1C1) and PGM-exposed (50 and $100 \mu \mathrm{g} / \mathrm{mL}$ ) treatment groups. Thus, we chose exposure doses of 50 and $100 \mu \mathrm{g} / \mathrm{mL}$ as nontoxic concentrations of PGM for in vivo experiments with zebrafish larvae. The cytotoxicity assay (MTT) results revealed that PGM was nontoxic to RAW 264.7 cells up to $500 \mu \mathrm{g} / \mathrm{mL}$ (Figure S1). Hence, we selected $200-400 \mu \mathrm{g} / \mathrm{mL}$ of PGM for in vitro experiments.

\subsection{Effect of PGM Exposure on Embryo Hatching in Zebrafish}

Figure 2A portrays the effect of PGM exposure on embryo hatching, and we found that there is a non-statistically significant increase in hatchability at $48 \mathrm{~h}$ post fertilization (hpf) that disappears by $72 \mathrm{hpf}$. Following $100 \mu \mathrm{g} / \mathrm{mL}$ PGM exposure, 59.92\% hatching was observed at $48 \mathrm{hpf}$, while $30.56 \%$ 
and $32.98 \%$ hatching success was recorded for the control and $50 \mu \mathrm{g} / \mathrm{mL}$ of PGM, respectively. In addition, irrespective of the level of exposure, all embryos were hatched (100\%) at $96 \mathrm{hpf}$. The relationship between early hatching and expression of hatching enzyme $1 \mathrm{~b}(\mathrm{helb})$ was investigated by transcriptional analysis. The expression level of the helb gene was significantly higher $(p<0.05)$ in PGM-exposed embryos than in the unexposed control group, at 24 hpf (Figure 2B). The helb expression was drastically $(p<0.05)$ reduced up to 0.3 -fold at $48 \mathrm{hpf}$ in PGM exposed to a higher dose $(100 \mu \mathrm{g} / \mathrm{mL})$ compared to the control. In addition, the $50 \mu \mathrm{g} / \mathrm{mL}$ of PGM-exposed group showed a downregulation (0.6-fold) which was not significant.

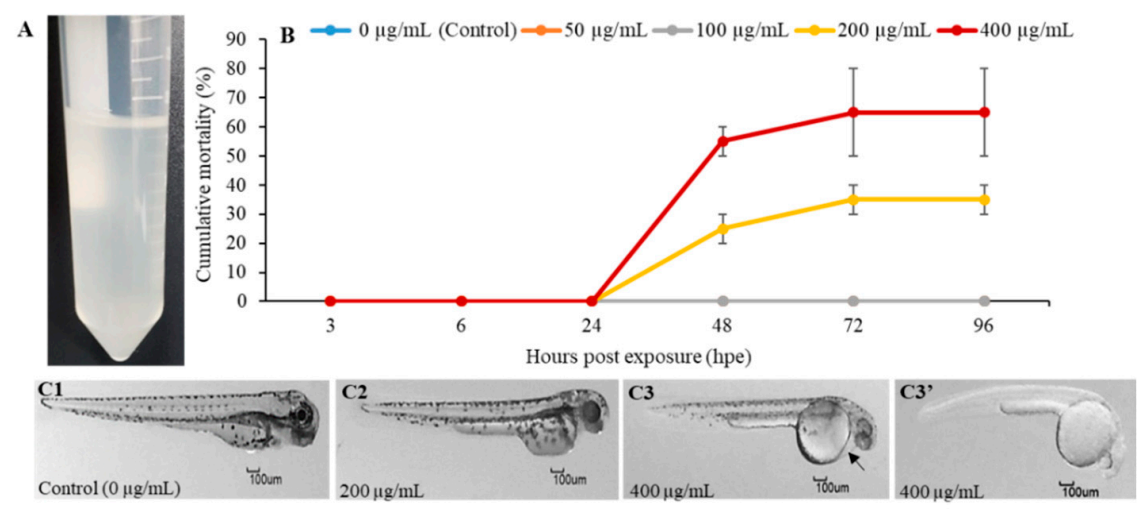

Figure 1. Solubility and effect of purified porcine gastric mucin (PGM) on the zebrafish embryos' toxicity. (A) Type III PGM stock solution ( $4 \mathrm{mg} / \mathrm{mL}$ ). (B) Mortality of zebrafish embryos exposed to PGM $(0-400 \mu \mathrm{g} / \mathrm{mL})$. Values are means standard error $( \pm \mathrm{SE})$ of duplicate independent experiments. (C2-C3') Representative examples of malformations caused by PGM exposure (200 and $400 \mu \mathrm{g} / \mathrm{mL}$ ) at $96 \mathrm{~h}$ post exposure (hpe). (C1) Control larva with normal appearance; (C2,C3') larva with spinal curvature; (C3) (black arrow) a slight pericardial edema in larva; $\left(\mathbf{C} 3, \mathbf{C}^{\prime}\right)$ larva with head malformations and underdeveloped embryos.
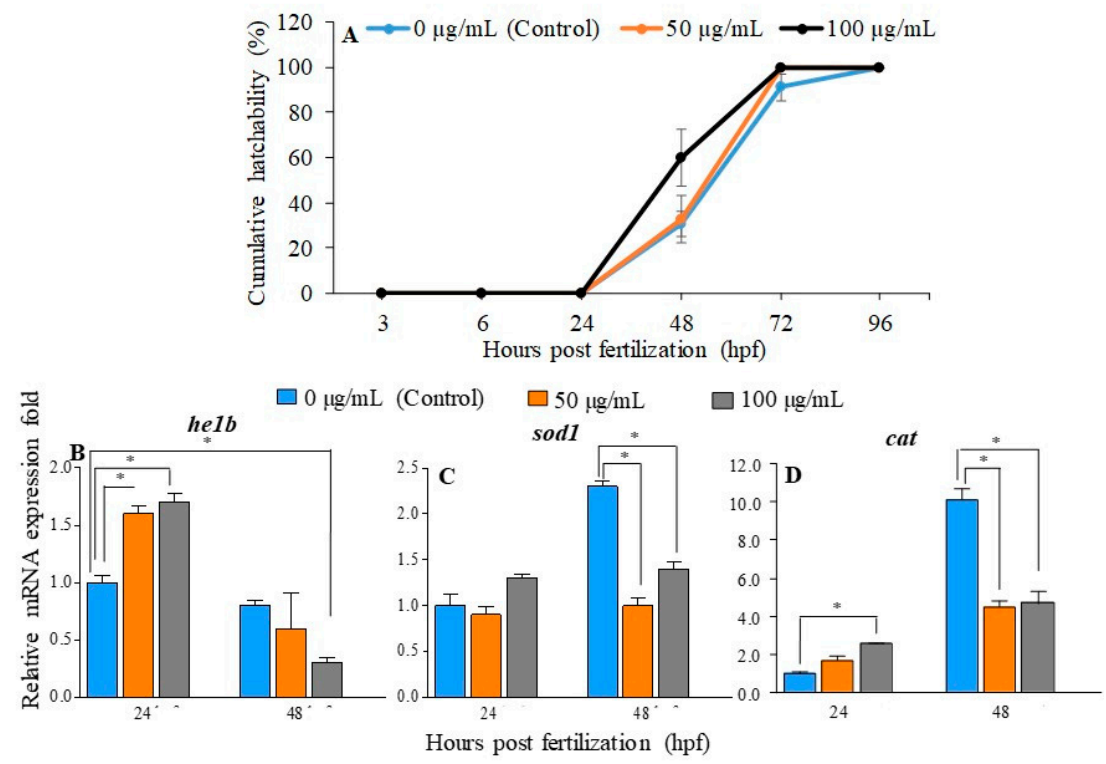

Figure 2. Effect of PGM on the hatching of zebrafish embryos. (A) Cumulative hatchability (\%) of zebrafish embryos at 50 and $100 \mu \mathrm{g} / \mathrm{mL}$ of PGM exposure. The relative mRNA expression of (B) he-1b, (C) sod1, and (D) cat on hatching upon PGM exposure (50 and $100 \mu \mathrm{g} / \mathrm{mL}$ ). Values are mean standard error $( \pm \mathrm{SE})$ of two independent experiments; asterisk marks are used to indicate the statistical significance compared to untreated control (two-way and one-way ANOVA, ${ }^{*} p<0.05$ ). 
Next, we analyzed the transcriptional expression of sod1 and cat as key antioxidant enzymes, to understand whether early hatching is associated with the level of ROS upon PGM exposure. At $24 \mathrm{hpf}$, the sod1 expression was observed at basal levels in the control and PGM-exposed groups, whereas cat gene expression was significantly $(p<0.05)$ induced $(2.6-$ fold $)$ in $100 \mu \mathrm{g} / \mathrm{mL}$ PGM-exposed embryos (Figure 2C,D). However, significantly high $(p<0.05)$ sod1 expression $(2.3$-fold) was detected in the untreated control group at $48 \mathrm{hpf}$. In contrast, the sod1 expression was significantly downregulated $(p<0.05)$ in 50 and $100 \mu \mathrm{g} / \mathrm{mL}$ of PGM exposure (0.9-fold and 1.4-fold, respectively) compared to the control at $48 \mathrm{hpf}$. The cat gene expression was significantly $(p<0.05)$ upregulated $(10.1$-fold $)$ in the control group at $48 \mathrm{hpf}$. In addition, PGM-exposed embryos showed significantly $(p<0.05)$ downregulated levels (4.5-fold and 4.7-fold) of cat at 50 and $100 \mu \mathrm{g} / \mathrm{mL}$, respectively, compared to the control at $48 \mathrm{hpf}$.

\subsection{Disease Resistance and Heat Tolerance of Zebrafish Larvae upon PGM Exposure}

To determine the disease resistance of PGM exposed larvae, relative percent survival (RPS) was analyzed after Aeromonas hydrophila challenge $\left(2.91 \times 10^{8} \mathrm{CFU} / \mathrm{mL}\right)$, until $96 \mathrm{~h}$ post infection (hpi). No mortality was observed in any of the groups, until 72 hpe. Interestingly, $85 \%$ and $94 \%$ higher survival rates were displayed in PGM-exposed larvae at 50 and $100 \mu \mathrm{g} / \mathrm{mL}$, respectively, compared to control (55\%) at 96 hpe (Figure 3A).



Figure 3. Effect of PGM on disease resistance and thermal tolerance in zebrafish larvae. (A) PGM-exposed (50 and $100 \mu \mathrm{g} / \mathrm{mL}$ ) zebrafish larvae (at 5 days post exposure (dpe)) were challenged with $A$. hydrophila $\left(2.91 \times 10^{8} \mathrm{CFU} / \mathrm{mL}\right)$, and percent survival rate was determined until $96 \mathrm{~h}$ post infection (hpi). (B) Zebrafish embryos exposed to 50 and $100 \mu \mathrm{g} / \mathrm{mL}$ of PGM and maintained at $28^{\circ} \mathrm{C}$ were subjected to heat stress at $40^{\circ} \mathrm{C}$ for $48 \mathrm{~h}$, and cumulative survival rate was calculated. The error bars indicate the mean standard error of three replicates.

Thermal tolerance of PGM-exposed larvae was determined by exposure to heat stress at $40{ }^{\circ} \mathrm{C}$ for $48 \mathrm{~h}$. Our results clearly indicated the concentration dependent heat tolerance in PGM-exposed (50 and $100 \mu \mathrm{g} / \mathrm{mL}$ ) larvae with $75 \%$ and $100 \%$ survival rate, respectively, compared to the control $(7 \%)$ at 12 hpe. However, PGM-exposed larvae groups (50 and $100 \mu \mathrm{g} / \mathrm{mL}$ ) failed to continue to have a high survival rate and decreased to zero level after 24 and $48 \mathrm{hpe}$, respectively.

\subsection{Detoxification Effect of PGM on Bacteria-Induced Oxidative Stress}

To examine whether PGM has any effect on reducing the oxidative stress upon A. hydrophila exposure, the level of ROS was measured in zebrafish larvae. As expected, the highly visible fluorescent distribution and relative intensity were observed in the head and pericardia $(181.2 \%)$ and tail $(278.4 \%)$ of $\mathrm{H}_{2} \mathrm{O}_{2}$ treated larvae (positive control), compared to the control group $(100 \%)$ without the PGM exposure (Figure 4A,B). The second highest fluorescent level was shown in the head and pericardia $(156.5 \%)$ 
of $A$. hydrophila-infected larvae, indicating that bacteria challenge causes the accumulation of ROS. As expected, the relative fluorescence was decreased in the group of $A$. hydrophila-infected larvae with the PGM treatment (head and pericardia: $87.4 \%$, and tail: $62.3 \%$ ), compared to A. hydrophila-infected larvae; however, the ROS-scavenging effect was not significant. Furthermore, the results evidenced that significantly $(p<0.05)$ decreased the fluorescence level in the PGM-exposed A. hydrophila-infected larvae, as compared to the control group. The lowest level of fluorescence $(16.6 \%)$ was in the tail of the larvae group exposed only to PGM, compared to the untreated control group. The PGM-treatment groups showed a similar fluorescence pattern in the head, pericardia, and tail, except the A. hydrophila treatment group. The overall results revealed PGM's ability to decrease the oxidative stress upon A. hydrophila exposure.

Control

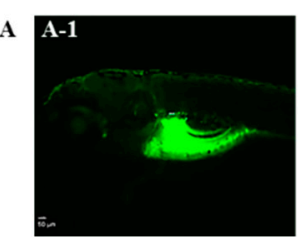

A-1'

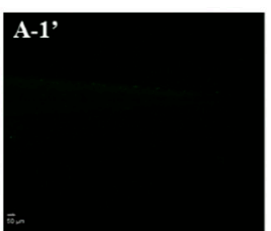

$\operatorname{PGM}(100 \mu \mathrm{g} / \mathrm{mL})$
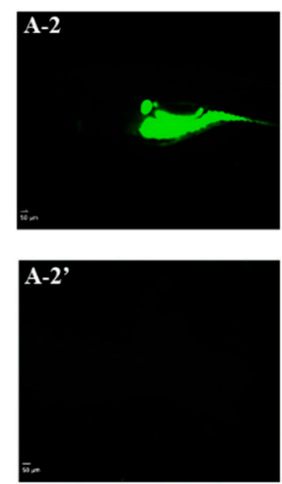

A. hyrdrophila
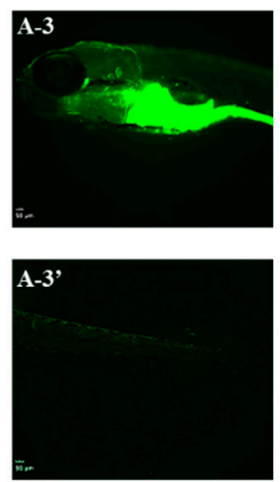

A. hvdrophila + PGM $(100 \mu \mathrm{g} / \mathrm{mL})$


$\mathrm{H}_{2} \mathrm{O}_{2}(5 \mathrm{mM})$
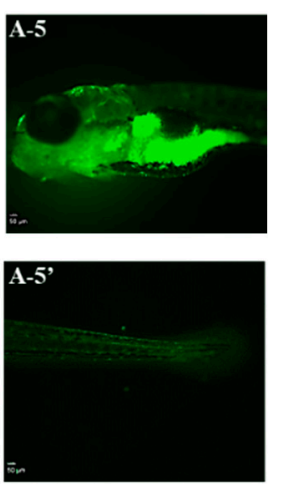

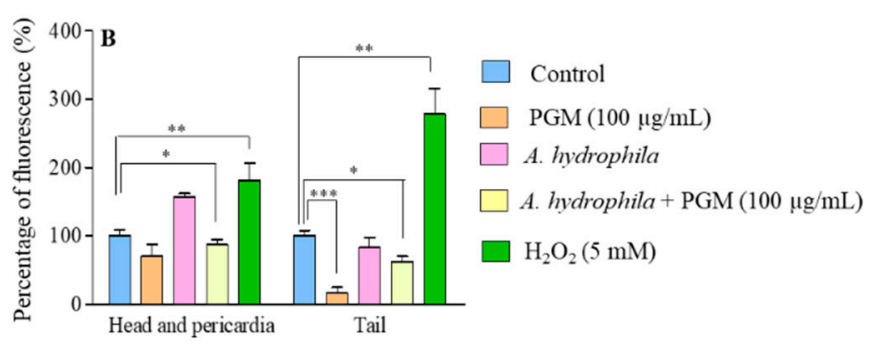

Figure 4. ROS detoxification effect of PGM on A. hydrophila-challenged zebrafish larvae. (A) Fluorescence images of head, pericardia, and tail areas were detected as follows: control: A-1 and A-1'; PGM $(100 \mu \mathrm{g} / \mathrm{mL}):$ A-2 and A-2'; A. hydrophila $\left(2.3 \times 10^{5} \mathrm{CFU} / \mathrm{mL}\right):$ A-3 and A- $3^{\prime}$; A. hydrophila + PGM $(100 \mu \mathrm{g} / \mathrm{mL}): \mathrm{A}-4$ and $\mathrm{A}-4^{\prime} ; \mathrm{H}_{2} \mathrm{O}_{2}(5 \mathrm{mM}): \mathrm{A}-5$ and A-5' . (B) The graph represents the percentage of fluorescence intensity over the untreated control group. Values were presented as means standard error $( \pm \mathrm{SE})$, and the asterisk marks are used to indicate the significant difference compared to the respective controls (one-way ANOVA, ${ }^{*} p<0.05,{ }^{* *} p<0.01,{ }^{* * *} p<0.001$ ).

\subsection{Transcriptional Analysis of Immune-Related Genes in PGM-Exposed Zebrafish Larvae}

Figure 5 interprets the relative mRNA expression levels of immune and antioxidant genes in PGM-exposed larvae for seven days. PGM-exposure (50 and $100 \mu \mathrm{g} / \mathrm{mL}$ ) demonstrated distinct immune and antioxidant gene expression profiles in the larvae, compared to the control group. Among the selected TLRs, $t \operatorname{lr} 5 a$ and $t \operatorname{lr} 5 b$ showed concentration-dependent upregulation ( $>2$-fold). Moreover, the transducing signaling pathway molecule (myd88) increased the expression (6.18-fold). A similar upregulation pattern was observed for transcription factor c-rel gene at $50 \mu \mathrm{g} / \mathrm{mL}$ (1.94-fold) and $100 \mu \mathrm{g} / \mathrm{mL}$ (2.35-fold) of PGM exposure (1.94-fold and 2.35-fold). Considering pro- and anti-inflammatory genes, $\operatorname{tn} f-\alpha$ and $i l 1 \beta$ showed concentration-dependent upregulation (>1.3-fold), where the expression was significant for $i l 1 \beta$ (1.98-fold) at $100 \mu \mathrm{g} / \mathrm{mL}$. In contrast, a 1.52 -fold induction was observed at $100 \mu \mathrm{g} / \mathrm{mL}$ for $i 110$, whereas no upregulation was observed for il6. In the group of chemokines, both $c x c l 18 b$ and $c c l 34 a .4$ were induced by $>2$-folds at the highest 
concentration $(100 \mu \mathrm{g} / \mathrm{mL})$. Among the antimicrobial genes, defbl, hamp, muc2.1, muc5.1, and muc5.2 showed concentration-dependent upregulations (>1.2-fold). In contrast, ctsd and muc5.3 were upregulated only at $50 \mu \mathrm{g} / \mathrm{mL}$ (1.91-fold), while $c h g A$ and $l y z-c$ showed no upregulation upon exposure. The stress-responsive genes $h s p 70$ (1.99-fold and 2.52-fold), hsp90aa1.1 (1.08-fold and 2.97-fold), and hsp90ab1 (1.73-fold and 2.48-fold) resulted in concentration-dependent upregulation at 50 and $100 \mu \mathrm{g} / \mathrm{mL}$, respectively. Additionally, the antioxidant enzyme cat showed slight upregulation (>1.14-fold), whereas sod1 was upregulated over 2.00 -fold at $50 \mu \mathrm{g} / \mathrm{mL}$.

\begin{tabular}{|c|c|c|c|c|}
\hline \multirow[b]{2}{*}{ Gene category } & \multicolumn{3}{|c|}{ Mucin concentration $(\mu \mathrm{g} / \mathrm{mL})$} & \\
\hline & Gene name & 50 & 100 & \\
\hline \multirow{5}{*}{$\begin{array}{l}\text { Toll like receptors and } \\
\text { transducing signaling } \\
\text { pathway molecules }\end{array}$} & $t \operatorname{lr} 2$ & 0.83 & 0.77 & $<0.50$ \\
\hline & $\operatorname{tl} 4$ & 0.87 & 0.65 & $0.50-0.79$ \\
\hline & $\operatorname{tl} 5 a$ & 1.41 & 2.06 & $0.80-0.99$ \\
\hline & $t \operatorname{tr} 5 b$ & 3.04 & 5.30 & 1.00 \\
\hline & myd88 & 2.05 & $6.18^{*}$ & $1.01-1.20$ \\
\hline Transcription factor & $c$-rel & 1.94 & 2.35 & $1.21-2.00$ \\
\hline \multirow[t]{4}{*}{ Pro and anti-inflammatory } & thfo. & 1.65 & 1.70 & $>2.00$ \\
\hline & ill $\beta$ & 1.30 & $1.98^{*}$ & \\
\hline & il6 & 0.74 & 1.08 & \\
\hline & illo & 0.94 & 1.52 & \\
\hline \multirow[t]{2}{*}{ Chemokines } & cxcll $8 b$ & 0.95 & 2.77 & \\
\hline & $\operatorname{ccl} 34 a .4$ & 1.10 & 2.20 & \\
\hline \multirow[t]{9}{*}{ Anti-microbial } & defbll & 2.11 & 3.67 & \\
\hline & hamp & 1.79 & 3.02 & \\
\hline & ctsd & 1.91 & 1.04 & \\
\hline & $\operatorname{chg} A$ & 0.62 & 0.73 & \\
\hline & muc2.1 & 1.25 & 2.02 & \\
\hline & muc5.1 & 1.51 & 1.97 & \\
\hline & muc5.2 & 2.76 & 3.00 & \\
\hline & muc5.3 & 1.45 & 0.93 & \\
\hline & $b y z-c$ & 0.43 & 0.78 & \\
\hline \multirow[t]{3}{*}{ Stress responsive } & hsp 70 & 1.99 & 2.52 & \\
\hline & hsp90aal.1 & 1.08 & 2.97 & \\
\hline & hsp90abl & 1.73 & 2.48 & \\
\hline \multirow[t]{2}{*}{ Antioxidant enzymes } & cat & 1.14 & 2.67 & \\
\hline & $\operatorname{sodl}$ & 2.00 & 1.51 & \\
\hline
\end{tabular}

Figure 5. The relative mRNA expression of immune and antioxidant genes in PGM-exposed zebrafish larvae. Embryos (2 days post fertilization (dpf)) were exposed to PGM $(0,50$, and $100 \mu \mathrm{g} / \mathrm{mL}$ ), and larvae were sampled at 7 dpe for isolating RNA. The asterisk marks are used to indicate the statistical significance compared to the control. Basal expression level was considered as 1.00-fold; upregulated and downregulated expressions were considered as $>1.01$-fold and $<0.80$-fold, respectively (one-way ANOVA, $\left.{ }^{*} p<0.05\right)$.

\subsection{PGM Effect on Hsp90 Protein Expression}

According to Figure 6A, PGM exposure (25, 50, and $100 \mu \mathrm{g} / \mathrm{mL})$ resulted in a concentration-dependent increase in Hsp90 protein in zebrafish larvae. A similar expression pattern was observed with the quantitative analysis, in which the relative Hsp90 protein expression was highest at $100 \mu \mathrm{g} / \mathrm{mL}$ of PGM exposure (2.25-fold), as compared to the control (Figure 6B). Among all the treatments, almost-equal expression levels of $\beta$-actin were observed. 

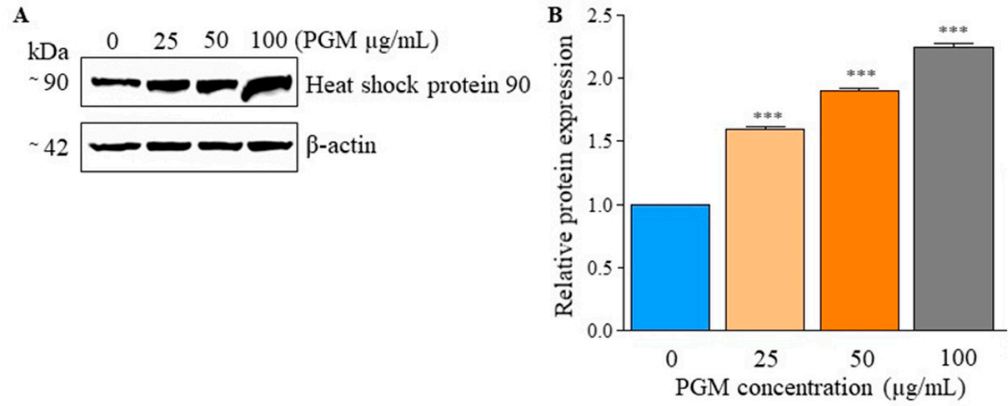

Figure 6. Expression of Hsp90 in PGM-exposed zebrafish larvae by immunoblot analysis. (A) Expression levels of Hsp90 in PGM-exposed (0, 25, 50, and $100 \mu \mathrm{g} / \mathrm{mL}$ ) larvae are shown (B) Quantitative analysis of Hsp90 expression in larvae is displayed with $\beta$-actin expression, relative to the untreated control. The asterisk marks are used to indicate statistical significance compared to the control (one-way ANOVA, $\left.{ }^{* * *} p<0.001\right)$.

\subsection{Transcriptional Analysis of Immune-Related Genes in PGM-Exposed RAW 264.7 Cells}

The mRNA expression levels of immune and antioxidant genes in RAW 264.7 are shown in Figure 7. The upregulation of pro-inflammatory genes (Il6 and Tnf- $\alpha$ ), anti-inflammatory (Il10), chemokine (Ccl3), antimicrobial genes (Defa-rs2, Defa21, and Camp), and antioxidant genes (Sod2 and Cat) was observed, while Toll-like receptors and signaling pathway molecules were downregulated. Particularly significant expression was detected for Tnf- $\alpha$ (5.10-fold and 5.65-fold), Ccl3 (28.86-fold and 27.03-fold), and Camp (6.56-fold and 12.87-fold) genes at 200 and $400 \mu \mathrm{g} / \mathrm{mL}$ of PGM exposure, respectively. Furthermore, significantly upregulated expression was shown for Il6, Il10, and Cat genes in PGM-treated RAW 264.7 cells at $400 \mu \mathrm{g} / \mathrm{mL}$.

\begin{tabular}{|c|c|c|c|c|}
\hline \multirow[b]{2}{*}{ Gene category } & \multirow[b]{2}{*}{ Gene name } & \multicolumn{2}{|c|}{ Mucin concentration $(\mu \mathrm{g} / \mathrm{mL})$} & \\
\hline & & 200 & 400 & \\
\hline \multirow{4}{*}{$\begin{array}{l}\text { Toll like receptors } \\
\text { and pathway } \\
\text { molecules }\end{array}$} & Tlr2 & 0.26 & 0.37 & $<0.50$ \\
\hline & Tlr4 & 0.16 & 0.31 & $0.50-0.79$ \\
\hline & Tlr5 & 0.05 & 0.16 & $0.80-0.99$ \\
\hline & Myd88 & 0.44 & 0.49 & 1.00 \\
\hline \multirow{3}{*}{$\begin{array}{l}\text { Pro and anti- } \\
\text { inflammatory genes }\end{array}$} & Il6 & 54.51 & $94.12 *$ & $1.01-1.20$ \\
\hline & Il10 & 2.36 & $5.62 *$ & $1.21-2.00$ \\
\hline & $\operatorname{Tnf} \alpha$ & $5.10 *$ & $5.65 * *$ & $>2.01$ \\
\hline \multirow{5}{*}{$\begin{array}{l}\text { Chemokine } \\
\text { Anti-microbial genes }\end{array}$} & $\mathrm{Ccl} 3$ & $28.86^{* *}$ & $27.03 * *$ & \\
\hline & Defa-rs2 & $3.87 * *$ & 2.02 & \\
\hline & Defa21 & $2.48 *$ & 0.41 & \\
\hline & Camp & $6.56^{*}$ & $12.87 * *$ & \\
\hline & Lyz1 & 0.59 & 0.40 & \\
\hline \multirow[t]{2}{*}{ Antioxidant enzymes } & Sod2 & 1.24 & 1.54 & \\
\hline & Cat & 1.47 & $2.07 *$ & \\
\hline
\end{tabular}

Figure 7. The relative mRNA expression of immune and antioxidant genes in PGM-treated RAW 264.7 cells. Cells were treated with PGM (200 and $400 \mu \mathrm{g} / \mathrm{mL})$ for $24 \mathrm{~h}$. The asterisk marks are used to indicate statistical significance compared with the control. Basal expression level was considered as 1.00-fold; upregulated and downregulated expressions were considered as $>1.01$ and $<0.80$-folds, respectively (one-way ANOVA, ${ }^{*} p<0.05,{ }^{* *} p<0.01$ ).

\section{Discussion}

In this study, we evaluated the toxicity effect of PGM on zebrafish embryos at different PGM concentrations, since performing toxicity and safety assessments is essential during the development of a new candidate of immunostimulants. Any compound can be toxic at higher doses; mostly, they are 
safe at very low levels. Moreover, the use of additives in the purification process of commercial mucin may be associated with the toxicity effects [16]. The signs of deformities were seen at $96 \mathrm{hpe}$ when the cumulative mortality rate was recorded as $>35 \%$ and $>65 \%$ for the 200 and $400 \mu \mathrm{g} / \mathrm{mL}$ concentrations of PGM, respectively. Therefore, as denoted by the $\mathrm{LC}_{50}$, we suggest that the safe concentration for the zebrafish would be $\leq 197.9 \mu \mathrm{g} / \mathrm{mL}$ of PGM. Moreover, Lieleg et al. (2012) [21] have reported that commercial PGM was not toxic to HeLa cells at $1 \%(w / v)$ solution at pH 7. Similarly, when RAW 264.7 cells were exposed to PGM, it was not toxic up to $500 \mu \mathrm{g} / \mathrm{mL}$. Collectively, these in vitro and in vivo nontoxic concentrations were considered to be biologically safe doses for our further studies.

Several factors, including environmental, physiological, biological, and genetic characteristics, may influence the fish-hatching process [22,23]. For instance, the $h e 1 a$ and $h e 1 b$ genes are induced prior to the hatching of zebrafish larvae [23]. Although the induced he1b expression was observed for both 50 and $100 \mu \mathrm{g} / \mathrm{mL}$ of PGM at $24 \mathrm{hpf}$, a lower hatchability \% was noted for lower doses of PGM $(50 \mu \mathrm{g} / \mathrm{mL})$ at $48 \mathrm{hpf}$. This difference might be due to the lack of one or more aforementioned factors.

Antioxidant enzymes such as SOD and CAT play an important role in mitigating and repairing the harmful effects of ROS by converting superoxide anion $\mathrm{O}_{2}{ }^{-}$into $\mathrm{H}_{2} \mathrm{O}_{2}$, and finally degrading into $\mathrm{H}_{2} \mathrm{O}$. Therefore, antioxidant enzymes assist in ensuring the antioxidant protection against deleterious ROS effects [24]. ROS are formed as a natural by-product during the normal metabolism of oxygen and are important in regular cell functioning [25]. Markedly, the increased expression of sod1 and cat in the control at $48 \mathrm{hpf}$ may have resulted from increased metabolic demand during hatching. However, sod1 and cat expressions were reduced when compared to that of the control at 48 hpf. PGM consist of ROS-scavenging properties in non-mucin components which enhance mucin's capacity to quench ROS [26]. In this study, a significantly lower expression of sod1 and cat upon PGM exposure confirmed its extensive ROS-scavenging properties. Therefore, this involvement may have caused a significant increase in the number of successfully hatched embryos.

Immunomodulation has the potential to elevate the larval survival rate by enhancing their innate immune responses until adaptive immunity becomes fully effective [27]. Previous studies have demonstrated the prophylactic use of immunostimulants to enhance the innate immune system of zebrafish against pathogenic infections during various stress conditions [28-31]. Interestingly, our study revealed the importance of PGM exposure on zebrafish larvae against A. hydrophila infection. Furthermore, results suggest that $100 \mu \mathrm{g} / \mathrm{mL}$ PGM is the most effective concentration for zebrafish larvae to activate innate immune responses against $A$. hydrophila infection. This clarifies the critical role of mucin as an exogenous stimulant in host-cell microbial interaction for the first time. The experiment result obtained from the thermal-tolerance activity of PGM revealed significant heat-stable properties of PGM, minimizing heat stress during zebrafish larval development. The PGM exposure $(100 \mu \mathrm{g} / \mathrm{mL})$ emphasizes its higher thermal tolerance capacity, with $100 \%$ survival rate and dose-dependent effectiveness at early stage of heat stress. This might be attributed to the functional role of membrane-associated MUC1-C in attenuating the activation of intrinsic apoptotic pathway and its interaction with heat-shock proteins (HSP70-HSP90) [32]. However, none of the concentrations was able to support larvae that were tolerant to the heat stress at $48 \mathrm{hpe}$.

In fish, ROSs are scavenged by non-enzymatic antioxidants and antioxidant enzymes [33]. Hong et al. (2015) [34] have suggested that the presence of mucins that are rich in threonine enhance the functions of fish digestive system by decreasing ROS level in common carp (Cyprinuscarpio L.). Previous in vitro biochemical assays also reported the anti-hydroxyl radical (AHR) scavenging capacity of PGM [35]. In this study, PGM significantly suppressed the ROS levels induced by A. hydrophila exposure in zebrafish larvae. Furthermore, it was confirmed that the presence of PGM alone reduces the ROS levels in the zebrafish larvae. These results suggest the potential role of PGM as an effective ROS-scavenging activity to alleviate bacteria-induced oxidative stress, and thus protecting cells from apoptosis. 
The soluble immunostimulants are usually absorbed by mucosal tissues and may subsequently activate immune responses in fish. This strategy has been suggested in protecting larval fish, as soluble immunostimulants can be easily taken up through their mucosal-epithelial barriers existing in organs such as gills and skin [36-38]. Therefore, PGM is an ideal immunostimulant for activating immune cells such as macrophages and lymphocytes and initiate further defense mechanisms. Toll-like receptors (TLRs) play a vital role in innate immunity by triggering the first line of defense against invasive pathogens [39]. Particularly, the TLR5 is known as the only protein-binding TLR that is conserved in vertebrates [40-42]. Hence, we could postulate one of the main roles of mucin as transcriptional activation of $t / r 5 a$ and $t l r 5 b$. Following TLR 5 stimulation and induction of myd88-dependent proinflammatory transcription factor, NF- $\mathrm{B}$, in various cells, such as epithelial cells, monocytes, and dendritic cells, may result in the activation of downstream innate immune responses [43]. The MYD88 is a critical adaptor protein in the TLR signaling pathway, as it is used by all TLRs except for TLR3 [44]. Van der Vaart et al. (2013) [45] demonstrated the protective role of MyD88 during early mycobacterial pathogenesis in zebrafish larvae. As a member of the transcription factor family NF- $\mathrm{KB}$ proteins, $\mathrm{c}-$ Rel modulates genes regulating multiple cellular processes from apoptosis to proliferation and inflammation [46]. Inflammatory cytokines such as IL-1 $\beta$ and TNF- $\alpha$ can activate the signaling pathway of the inflammatory responses [47]. The il1 $\beta$ is one of the early responding pro-inflammatory cytokines that allows organisms to react against infectious insults, stimulating an inflammatory cascade, along with other defensive reactions [48]. Significant upregulation of $i l 1 \beta$ suggests the involvement of mucin in activating the signaling pathway of inflammatory responses. Chemokines (cxcl18b and ccl34a.4) are ubiquitous cytokine molecules that also play a significant role in the immunological and physiological functions of the fish [49].

Cobo et al. (2015) [50] suggested the involvement of MUC2 in regulating the expression of the antimicrobial activity of $\beta$-defensin 2 , where in vivo mice experiments exhibited reduced expression of $\beta$-defensin in Muc2-/- (homozygous) in mice colon, when compared to mice with Muc2 $^{+/-}$(heterozygous) and Muc2 ${ }^{+/+}$. Similarly, in this study, upon PGM exposure, the upregulation of endogenous muc2.1 and other mucin genes may have induced the expression of antimicrobial peptides such as $\beta$ defensin1, hepcidin, and cathepsin $D$. Concentration-dependent PGM exposure upregulated $h s p 70, h s p 90 a a 1.1$, and $h s p 90 a b 1$ mRNA levels at 7 days post exposure (dpe), and it is further evidenced by the induction of Hsp90 by Western blotting. This also may have resulted due to the functional role of MUC1-C, as we described earlier for heat resistance of zebrafish larvae at 5 dpe [32]. In addition, Hsp70 and Hsp90 may be responsible for targeting MUC-1C to the mitochondrial outer membrane through the delivery of proteins [32]. These proteins actively protect and recover the functions of various protein complexes [51]. Importantly, Hsp90 is noncovalently associated with the immunogenic peptides, highlighting their potential role in regulating immune responses [52]. Therefore, a high abundance of Hsp90 protein suggests that mucin may alter the immune responses in zebrafish. The upregulation of antioxidant enzymes (cat and sod1) further confirms that mucin may reduce oxidative stress by triggering the release of antioxidant-related genes, to overcome the stress conditions. Overall results suggest the active role of PGM as an immunostimulant in regulating immune responses.

Kono and Sakai (2001) [53] reported the activation of macrophages and lymphocytes in fish after being treated with immunostimulants. Antigen-presenting cells such as macrophages express pathogen recognition receptors (PRRs), which are used for the detection of pathogen-associated molecular patterns (PAMPs) [54]. Macrophages play a key role in inflammatory responses by secreting pro- and anti-inflammatory cytokines such as IL-1 $\beta$, IL-6, TNF- $\alpha$, and IL-10 [55]. Therefore, the significant expression of pro-inflammatory genes in PGM-exposed RAW 264.7 cells reveals that it may activate the immune response pathways similar to zebrafish in this study. This was further confirmed by the induced expression of antimicrobial and antioxidant genes which were observed similar to zebrafish. The reason for downregulated Toll-like receptors and pathway molecules perhaps related to the upregulation of an anti-inflammatory cytokine (Il-10). IL-10 is involved in inhibiting pro-inflammatory cytokines, expression of anti-inflammatory responses, and phagocytic activity [56]. 
Therefore, the induced pro- and anti-inflammatory cytokines by PGM exposure highlight its immune modulatory role in RAW cells.

\section{Materials and Methods}

\subsection{Preparation of PGM Solution}

To prepare a stock solution, $200 \mathrm{mg}$ of type III PGM (Sigma-Aldrich, St Louis, MO, USA) was dissolved in $50 \mathrm{~mL}$ autoclaved distilled water, at room temperature $\left(25^{\circ} \mathrm{C}\right)$. The $\mathrm{pH}$ of the stock solution of PGM $(4 \mathrm{mg} / \mathrm{mL}$ ) was measured by using a digital $\mathrm{pH}$ meter (Thermo Scientific, Waltham, MA, USA). The stock solution was diluted with autoclaved distilled water, according to the required concentration of PGM for different assays.

\subsection{Cell Culture and Cytotoxicity of PGM}

The RAW 264.7 murine macrophage cells were cultured in Dulbecco's modified Eagle medium (WELGENE Inc., Daegu, Korea) with 10\% ( $v / v)$ fetal bovine serum (WELGENE Inc., Daegu, Korea) and antibiotic-antimycotic solution (Gibco ${ }^{\mathrm{TM}}$, GrandIsland, NY, USA). The cells were incubated at $37^{\circ} \mathrm{C}$, in a humidified atmosphere containing $5 \% \mathrm{CO}_{2}$, and the medium was replaced daily. Cells were seeded $(100 \mu \mathrm{L} /$ well $)$ in a 96-well flat-bottom microtiter plate, at a density of $2.0 \times 10^{5}$ cells $/ \mathrm{mL}$, and allowed to adhere overnight. The medium was replaced, and cell cytotoxicity was determined by MTT (3-[4,5-dimethylthiazol-2-yl]-2,5-diphenyltetrazolium bromide; Sigma-Aldrich, St Louis, MO, USA) assay. In brief, cells were treated for $24 \mathrm{~h}$ with $10-500 \mu \mathrm{g} / \mathrm{mL}$ of PGM. Autoclaved distilled water was used as the negative control. After incubation, the medium was replaced, and $10 \mu \mathrm{L}$ of MTT solution $(5 \mathrm{mg} / \mathrm{mL}$ in phosphate-buffered saline (PBS)) was added to each well and incubated for $4 \mathrm{~h}$ at $37^{\circ} \mathrm{C}$. The medium was removed, and $50 \mu \mathrm{L}$ of dimethyl sulfoxide (DMSO; Sigma-Aldrich, St Louis, $\mathrm{MO}$, USA) was added, to solubilize the formazan crystals. The absorbance was measured at $595 \mathrm{~nm}$, using a microplate spectrophotometer (Bio-Rad Laboratories, Inc., Richmond, CA, USA).

\subsection{Determination of In Vivo Toxicity of PGM on Zebrafish Embryos}

Wild-type adult zebrafish were raised at $28.5^{\circ} \mathrm{C}$, in an automated circulatory system, under a 14:10 h light:dark schedule. Embryos were obtained and raised until larvae stage ( $7 \mathrm{dpf})$, in standard Petri dishes $(90 \times 20 \mathrm{~mm})$ containing embryo water with aquarium salt $(60 \mathrm{mg} / \mathrm{L})$, at $28.5^{\circ} \mathrm{C}$. Healthy zebrafish embryos ( $2 \mathrm{hpf}$ ) were selected, and 10 embryos per well (3 replicates/treatment) were incubated in 6-well plates with $10 \mathrm{~mL}$ of embryonic water. Then the embryos were exposed to serially diluted PGM $(50,100,200$, and $400 \mu \mathrm{g} / \mathrm{mL})$. The embryonic water was used as the control. Mortality was observed up to $96 \mathrm{hpe}$. To determine the nontoxic levels of PGM to embryos, $\mathrm{LC}_{50}$ was calculated (https://www.aatbio.com/tools/lc50-calculator). Additionally, phenotypic abnormalities in zebrafish larvae upon PGM exposure were observed, using light microscopy (Nikon, SMZ1000, Tokyo, Japan), and the images were captured with a digital camera (Moticam Pro205, San Antonio, TX, USA), at 96 hpe. The experiment was carried out twice, to increase the accuracy. After determining the nontoxic concentrations, 50 and $100 \mu \mathrm{g} / \mathrm{mL}$ of PGM were selected for further experiments.

\subsection{Effect of PGM on Zebrafish Hatching}

To examine the effect of PGM on hatching, zebrafish embryos were exposed to 50 and $100 \mu \mathrm{g} / \mathrm{mL}$ of PGM, as mentioned in Section 4.3. Then the hatchability was monitored, and the hatching rate was calculated up to 48 hpe. In addition, embryos $(n=50)$ were placed in Petri dishes containing $50 \mathrm{~mL}$ of embryonic water (control) and similar concentrations of PGM. The exposed embryos and hatched larvae were collected at 24 and $48 \mathrm{hpe}$, snap-frozen in liquid nitrogen, and then stored at $-80^{\circ} \mathrm{C}$, until RNA isolation. To increase the accuracy, the experiment was carried out twice. 


\subsection{PGM Effect on A. hydrophila Challenge and Heat Resistance in Zebrafish Larvae}

To investigate the disease-resistance capacity of PGM, zebrafish embryos were exposed to 50 and $100 \mu \mathrm{g} / \mathrm{mL}$ of PGM, as mentioned in Section 4.3. The PGM-exposed larvae and the control larvae (without PGM exposure) at $5 \mathrm{dpf}$ were bath-immersed with pathogenic A. hydrophila $\left(2.91 \times 10^{8} \mathrm{CFU} / \mathrm{mL}\right)$, and the cumulative survivals were recorded until $96 \mathrm{hpi}$. To examine the heat resistance of PGM on zebrafish larvae, PGM-exposed embryos were maintained at $28{ }^{\circ} \mathrm{C}$, and 5 dpf larvae were subjected to heat stress by incubating at $40^{\circ} \mathrm{C}$. The cumulative survivals were recorded until 48 hpe, and the experiment was carried out twice.

\subsection{Analysis of ROS Production in PGM Exposed Larvae Upon A. hydrophila Challenge}

To measure the effect of PGM on ROS detoxification, zebrafish larvae were grouped as (1) control, (2) PGM (100 $\mu \mathrm{g} / \mathrm{mL}),(3)$ A. hydrophila $\left(2.3 \times 10^{5} \mathrm{CFU} / \mathrm{mL}\right),(4)$ PGM $(100 \mu \mathrm{g} / \mathrm{mL})+$ A. hydrophila, and (5) positive control, $\mathrm{H}_{2} \mathrm{O}_{2}(5 \mathrm{mM})$. The embryos in Groups 2 and 3 were exposed to $100 \mu \mathrm{g} / \mathrm{mL}$ of PGM, as described under Section 4.3. After $5 \mathrm{dpf}$, the larvae in Groups 3 and 4 were challenged with A. hydrophila, according to the method described in Section 4.5. The level of ROS in larvae in all the groups was measured at $48 \mathrm{hpi}$. Initially, larvae were stained, using $(5 \mu \mathrm{g} / \mathrm{mL})$ fluorescent dye, $2^{\prime} 7^{\prime}$ dichloro-dihydro-fluorescein diacetate ( $\mathrm{H}_{2}$ DCFDA; Sigma-Aldrich, St Louis, MO, USA), for 30 min, at $28{ }^{\circ} \mathrm{C}$, in the dark. The excess dye was washed 4 times, and intracellular ROS generation in the head, pericardia, and tail areas was detected under a microscope (Nikon SMZ1000, Tokyo, Japan) equipped with fluorescence filter (Chroma, Bellows Falls, VT, USA). The fluorescence intensity of individual larvae was quantified by ImageJ software (ImageJ, version 1.6, Bethesda, MD, USA), and the percentage of fluorescence intensity was calculated compared to the untreated control.

\subsection{Isolation of Total RNA and Quantitative Real-Time Polymerase Chain Reaction (qRT-PCR)}

To determine the immune modulation effect of PGM, qRT-PCR) was performed in larvae exposed to PGM from the embryonic stage and in PGM-treated RAW 264.7 cells. Briefly, RAW 264.7 cells $\left(2.0 \times 10^{5}\right.$ cells $\left./ \mathrm{mL}\right)$ were seeded in a 6-well plate and allowed to adhere overnight (3 replicates/treatment). Cells were maintained as described in the Section 4.3. After replacing the medium, the cells were exposed to 200 and $400 \mu \mathrm{g} / \mathrm{mL}$ of PGM, at $37^{\circ} \mathrm{C}$, for $24 \mathrm{~h}$, in a $\% \mathrm{CO}_{2}$ incubator. Following the aspiration of the medium, cells were washed in PBS and centrifuged at $300 \mathrm{~g}$ for $5 \mathrm{~min}$. After complete removal of the supernatant, the cell pellet was stored at $-80^{\circ} \mathrm{C}$, until isolation of RNA. In addition, 50 embryos containing $50 \mathrm{~mL}$ of embryonic water in Petri dishes were exposed to 50 and $100 \mu \mathrm{g} / \mathrm{mL}$ of PGM, until $7 \mathrm{dpe}$, and the larvae were snap-frozen in liquid nitrogen and stored at $-80^{\circ} \mathrm{C}$, until RNA isolation. Total RNA was extracted by using Tri Reagent ${ }^{\mathrm{TM}}$ kit (Sigma-Aldrich, St Louis, MO, USA), following the manufacturer's protocol. A total of $2.5 \mu \mathrm{g}$ of total RNA was reverse-transcribed by the Prime Script ${ }^{\mathrm{TM}}$ first-strand cDNA synthesis kit (TaKaRa ${ }^{\circledR}$, Tokyo, Japan), diluted $40 \times$, and stored at $-20^{\circ} \mathrm{C}$. The qRT-PCR was performed to analyze the gene expression in PGM-treated cells, larvae, and controls, using a Thermal Cycler Dice Real Time System (TaKaRa, Tokyo, Japan). Zebrafish $\beta$-actin and mouse Gapdh were used as the housekeeping genes, and the reaction was performed according to a method described in our previous study [57]. The expression fold was calculated by the $2^{-(\Delta \Delta C T)}$ method [58]. The description of the gene-specific primer sequences is shown in Supplementary Table S1.

\subsection{Immunoblot Analysis for Hsp90 Expression in Zebrafish Larvae}

For analyzing the Hsp90 protein expression, zebrafish embryos $(n=35)$ were exposed to 25,50 , and $100 \mu \mathrm{g} / \mathrm{mL}$ of PGM, until 7 dpe. Then, the collected larvae were snap-frozen in liquid nitrogen and stored at $-80^{\circ} \mathrm{C}$, till use. The larvae were homogenized in a lysis buffer, pH 7.6 (ProEX ${ }^{\mathrm{TM}} \mathrm{CETi}$, TransLab Inc, Daejeon, Korea) and protein concentration was measured by using Bradford assay (Bio-Rad Laboratories, Inc., Hercules, CA, USA). Samples were then denatured with 2x Laemmli sample buffer (Sigma Aldrich, St Louis, MO, USA), at $100^{\circ} \mathrm{C}$, for $5 \mathrm{~min}$. A sample $(50 \mu \mathrm{g})$ of each PGM-treated 
and control group was loaded and separated by 10\% SDS-PAGE, followed by transferring onto an Immobilon-P polyvinylidene difluoride (PVDF) membrane (Millipore, Bedford, MA, USA) for 2 h, using Trans-Blot semidry transfer cell (Bio-Rad Laboratories, Inc., Hercules, CA, USA). The membrane was blocked for $1 \mathrm{~h}$ in Tris-buffered saline with 5\% bovine serum albumin (BSA) and 0.05\% Tween20 (TBST), followed by overnight incubation with primary antibodies, anti-heat-shock protein 90-Hsp90 (Cell Signaling Technology; \#4874) and anti- $\beta$-actin (C4) (Santa Cruz Biotechnology; SC-47778) at $4{ }^{\circ} \mathrm{C}$. On the following day, membranes were washed 3 times with PBS containing $0.05 \%$ Tween20 (PBST), for $10 \mathrm{~min}$, and incubated at room temperature with 1:3000 of horseradish peroxidase (HRP)-conjugated secondary antibodies, anti-rabbit IgG antibody (HRP) (Cell Signaling Technology; \#7074) for Hsp90, and mouse IgG antibody (HRP) (GeneTex; GTX213111-01) for $\beta$-actin in TBST, for $1 \mathrm{~h}$, respectively. Then, the membranes were washed 3 times, for $10 \mathrm{~min}$, with PBST, followed by HRP developing with Western blotting detection reagent (Western Femto ECL Kit, LPS Solution, Daejeon, Korea). This was visualized by using a chemiluminescence detection system (Fusion Solo S, Vilber, Lourmat, France). Simultaneously, protein bands of Hsp90 and $\beta$-actin were quantified by Evolution-CAPT software (FUSION software user and service manual-v17.03, Vilber, Lourmat, France) and normalized with the $\beta$-actin, to find the relative Hsp90 protein expression compared to the control.

\subsection{Statistical Analysis}

The statistical differences of cumulative mortality, hatchability, survival upon A. hydrophila challenge, and heat stress were analyzed at each time point, compared to that of the control, using one-way analysis of variance (ANOVA). To assess the concentration- and time-dependent $h e 1 b$ mRNA expression analysis, two-way ANOVA was used. The significant differences of sod1 and cat mRNA expressions were analyzed, comparing with the controls at respective time point, using one-way ANOVA. The statistical significance of fluorescence percentage and other experiments on mRNA expressions were analyzed, compared to that of the control, using one-way ANOVA. Tukey's test was used for the mean comparison. The significant differences were defined at $p<0.05$, and data were presented as mean \pm SE for three replicates. The data were statistically analyzed, using the GraphPad Prism software version 5 (GraphPad Software Inc., San Diego, CA, USA).

\section{Conclusions}

Collectively, our results suggest that PGM may potentially be involved with the embryonic hatching process and ROS-scavenging activity, as well as enhance the disease and thermal resistance, and immunomodulation in zebrafish larvae. This study revealed that PGM is involved in the regulation of transcriptional gene induction to increase Hsp90 protein in the zebrafish larvae. Particularly, this study is the first to use exogenous PGM as an immunostimulant in fish. Hence, our overall findings shed light on the potential applications of PGM as a biomaterial which modulates the immune system of fish and thereby protects the host from pathogenic invasions. Furthermore, we believe that this study may ultimately contribute to develop PGM-based therapeutic strategies to control and prevent diseases in fish.

Supplementary Materials: The following are available online. Figure S1. Effect of PGM on the viability of RAW 264.7 cells. The cells were treated with PGM $(0-500 \mu \mathrm{g} / \mathrm{mL})$ for $24 \mathrm{~h}$, and cell viability was assessed by MTT assay. The results were expressed as the percentage of surviving cells over untreated control cells. Values were presented as means \pm SE. Table S1. Description of the selected gene specific primers used in this study.

Author Contributions: Conceptualization, I.W., G.-J.H., and M.D.Z.; funding acquisition, M.D.Z. and I.W.; project administration, I.W. and M.D.Z.; resources, M.D.Z.; supervision, I.W., G.-J.H., and M.D.Z.; review and editing, I.W. and M.D.Z.; formal analysis, C.N., S.L.E., T.D.L., and P.S.D; methodology, M.D.Z.; writing—review and editing, M.D.Z.; investigation, C.N., S.L.E., T.D.L., and P.S.D; writing-original draft, T.D.L. and P.S.D.; writing一review and editing, C.N. All authors have read and agreed to the published version of the manuscript.

Funding: This work was supported by the National Research Foundation of Korea (NRF) grants, funded by the Korea government (MSIT) (2018R1A2B6007841 and 2019R1A2C1087028). This work was also supported by 
the Research Program of the National Marine Biodiversity Institute of Korea (MABIK), funded by the Korea government (MOF) (2020M00600).

Conflicts of Interest: The authors declare no conflicts of interest.

Ethics Approval: All experiments with zebrafish were conducted in accordance with the approved guidelines and regulations of the Animal Ethics Committee of Chungnam National University (CNU-00866).

\section{References}

1. John, G.; Mesalhy, S.; Rezk, M.; El-Naggar, G.; Fathi, M. Effect of some immunostimulants as feed additives on the survival and growth performance of Nile tilapia, Oreochromis niloticus and their response to artificial infection. Egypt. J. Aquat. Biol. Fish. 2007, 11, 1299-1308.

2. Wang, W.; Sun, J.; Liu, C.; Xue, Z. Application of immunostimulants in aquaculture: Current knowledge and future perspectives. Aquac. Res. 2017, 48, 1-23. [CrossRef]

3. Devine, P.L.; McKenzie, I.F.C. Mucins: Structure, function, and associations with malignancy. BioEssays 1992, 14, 619-625. [CrossRef] [PubMed]

4. Lesuffleur, T.; Zweibaum, A.; Real, F.X. Mucins in normal and neoplastic human gastrointestinal tissues. Crit. Rev. Oncol. Hematol. 1994, 17, 153-180. [CrossRef]

5. Gendler, S.J.; Spicer, A.P. Epithelial mucin genes. Annu. Rev. Physiol. 1995, 57, 607-634. [CrossRef]

6. Seregni, E.; Botti, C.; Massaron, S.; Lombardo, C.; Capobianco, A.; Bogni, A.; Bombardieri, E. Structure, function and gene expression of epithelial mucins. Tumori J. 1997, 83, 625-632. [CrossRef]

7. Van Klinken, B.J.W.; Einerhand, A.W.C.; Büller, H.A.; Dekker, J. Strategic biochemical analysis of mucins. Anal. Biochem. 1998, 265, 103-116. [CrossRef]

8. Strous, G.J.; Dekker, J. Mucin-type glycoproteins. Crit. Rev. Biochem. Mol. Biol. 1992, 27, 57-92. [CrossRef]

9. Johansson, M.E.V.; Sjövall, H.; Hansson, G.C. The gastrointestinal mucus system in health and disease. Nat. Rev. Gastroenterol. Hepatol. 2013, 10, 352-361. [CrossRef]

10. Leal, J.; Smyth, H.D.C.; Ghosh, D. Physicochemical properties of mucus and their impact on transmucosal drug delivery. Int. J. Pharm. 2017, 532, 555-572. [CrossRef]

11. Dhanisha, S.S.; Guruvayoorappan, C.; Drishya, S.; Abeesh, P. Mucins: Structural diversity, biosynthesis, its role in pathogenesis and as possible therapeutic targets. Crit. Rev. Oncol. Hematol. 2018, 122, 98-122. [CrossRef] [PubMed]

12. Çelebioğlu, H.Y.; Lee, S.; Chronakis, I.S. Interactions of salivary mucins and saliva with food proteins: A review. Crit. Rev. Food Sci. Nutr. 2020, 60, 64-83. [CrossRef]

13. Pelaseyed, T.; Bergström, J.H.; Gustafsson, J.K.; Ermund, A.; Birchenough, G.M.H.; Schütte, A.; van der Post, S.; Svensson, F.; Rodríguez-Piñeiro, A.M.; Nyström, E.E.L.; et al. The mucus and mucins of the goblet cells and enterocytes provide the first defense line of the gastrointestinal tract and interact with the immune system. Immunol. Rev. 2014, 260, 8-20. [CrossRef] [PubMed]

14. Birchenough, G.M.H.; Johansson, M.E.V.; Gustafsson, J.K.; Bergström, J.H.; Hansson, G.C. New developments in goblet cell mucus secretion and function. Mucosal Immunol. 2015, 8, 712-719. [CrossRef] [PubMed]

15. Martínez-Sáez, N.; Peregrina, J.M.; Corzana, F. Principles of mucin structure: Implications for the rational design of cancer vaccines derived from MUC1-glycopeptides. Chem. Soc. Rev. 2017, 46, 7154-7175. [CrossRef] [PubMed]

16. Schömig, V.J.; Käsdorf, B.T.; Scholz, C.; Bidmon, K.; Lieleg, O.; Berensmeier, S. An optimized purification process for porcine gastric mucin with preservation of its native functional properties. RSC Adv. 2016, 6, 44932-44943. [CrossRef]

17. Neuhaus, H.; Van der Marel, M.; Caspari, N.; Meyer, W.; Enss, M.L.; Steinhagen, D. Biochemical and histochemical study on the intestinal mucosa of the common carp Cyprinus carpio L., with special consideration of mucin glycoproteins. J. Fish Biol. 2007, 70, 1523-1534. [CrossRef]

18. Schroers, V.; van der Marel, M.; Neuhaus, H.; Steinhagen, D. Changes of intestinal mucus glycoproteins after peroral application of Aeromonas hydrophila to common carp (Cyprinus carpio). Aquaculture 2009, 288, 184-189. [CrossRef]

19. Padra, J.T.; Pagneux, Q.; Bouckaert, J.; Jijie, R.; Sundh, H.; Boukherroub, R.; Lindén, S.K. Mucin modified SPR interfaces for studying the effect of flow on pathogen binding to Atlantic salmon mucins. Biosens. Bioelectron. 2019, 146, 111736. [CrossRef] 
20. Jessberger, N.; Dietrich, R.; Mohr, A.K.; Da Riol, C.; Märtlbauer, E. Porcine gastric mucin triggers toxin production of enteropathogenic Bacillus cereus. Infect. Immun. 2019, 87. [CrossRef]

21. Lieleg, O.; Lieleg, C.; Bloom, J.; Buck, C.B.; Ribbeck, K. Mucin biopolymers as broad-spectrum antiviral agents. Biomacromolecules 2012, 13, 1724-1732. [CrossRef] [PubMed]

22. Korwin-Kossakowski, M. Fish hatching strategies: A review. Rev. Fish Biol. Fish. 2012, 22, 225-240. [CrossRef]

23. Armant, O.; Gombeau, K.; El Houdigui, S.M.; Floriani, M.; Camilleri, V.; Cavalie, I.; Adam-Guillermin, C. Zebrafish exposure to environmentally relevant concentration of depleted uranium impairs progeny development at the molecular and histological levels. PLoS ONE 2017, 12, e0177932. [CrossRef] [PubMed]

24. Valavanidis, A.; Vlahogianni, T.; Dassenakis, M.; Scoullos, M. Molecular biomarkers of oxidative stress in aquatic organisms in relation to toxic environmental pollutants. Ecotoxicol. Environ. Saf. 2006, 64, 178-189. [CrossRef]

25. Vinagre, C.; Madeira, D.; Narciso, L.; Cabral, H.N.; Diniz, M. Effect of temperature on oxidative stress in fish: Lipid peroxidation and catalase activity in the muscle of juvenile seabass, Dicentrarchus labrax. Ecol. Indic. 2012, 23, 274-279. [CrossRef]

26. Brownlee, I.A.; Knight, J.; Dettmar, P.W.; Pearson, J.P. Action of reactive oxygen species on colonic mucus secretions. Free Radic. Biol. Med. 2007, 43, 800-808. [CrossRef]

27. Bricknell, I.; Dalmo, R.A. The use of immunostimulants in fish larval aquaculture. Fish Shellfish Immunol. 2005, 19, 457-472. [CrossRef]

28. Oyarbide, U.; Rainieri, S.; Pardo, M.A. Zebrafish (Danio rerio) larvae as a system to test the efficacy of polysaccharides as immunostimulants. Zebrafish 2012, 9, 74-84. [CrossRef]

29. Brun, N.R.; Lenz, M.; Wehrli, B.; Fent, K. Comparative effects of zinc oxide nanoparticles and dissolved zinc on zebrafish embryos and eleuthero-embryos: Importance of zinc ions. Sci. Total Environ. 2014, 476-477, 657-666. [CrossRef]

30. Udayangani, R.M.C.; Dananjaya, S.H.S.; Fronte, B.; Kim, C.H.; Lee, J.; De Zoysa, M. Feeding of nano scale oats $\beta$-glucan enhances the host resistance against Edwardsiella tarda and protective immune modulation in zebrafish larvae. Fish Shellfish Immunol. 2017, 60, 72-77. [CrossRef]

31. Nikapitiya, C.; Dananjaya, S.H.S.; De Silva, B.C.J.; Heo, G.J.; Oh, C.; De Zoysa, M.; Lee, J. Chitosan nanoparticles: A positive immune response modulator as display in zebrafish larvae against Aeromonas hydrophila infection. Fish Shellfish Immunol. 2018, 76, 240-246. [CrossRef] [PubMed]

32. Ren, J.; Agata, N.; Chen, D.; Li, Y.; Yu, W.; Huang, L.; Raina, D.; Chen, W.; Kharbanda, S.; Kufe, D. Human MUC1 carcinoma-associated protein confers resistance to genotoxic anticancer agents. Cancer Cell 2004, 5, 163-175. [CrossRef]

33. Martínez-Álvarez, R.M.; Morales, A.E.; Sanz, A. Antioxidant defenses in fish: Biotic and abiotic factors. Rev. Fish Biol. Fish. 2005, 15, 75-88. [CrossRef]

34. Hong, Y.; Jiang, W.; Kuang, S.; Hu, K.; Tang, L.; Liu, Y.; Jiang, J.; Zhang, Y.; Zhou, X.; Feng, L. Growth, digestive and absorptive capacity and antioxidant status in intestine and hepatopancreas of sub-adult grass carp Ctenopharyngodon idella fed graded levels of dietary threonine. J. Anim. Sci. Biotechnol. 2015, 6, 34. [CrossRef]

35. Grisham, M.B.; Von Ritter, C.; Smith, B.F.; Lamont, J.T.; Granger, D.N. Interaction between oxygen radicals and gastric mucin. Am. J. Physiol. 1987, 253, G93-G96. [CrossRef]

36. Zapata, A.G.; Torroba, M.; Alvarez, F.; Anderson, D.P.; Dixon, O.W.; Wisniewski, M. Electron microscopic examination of antigen uptake by salmonid gill cells after bath immunization with a bacterin. J. Fish Biol. 1987, 31, 209-217. [CrossRef]

37. Dalmo, R.A.; Bøgwald, J. $\beta$-glucans as conductors of immune symphonies. Fish Shellfish Immunol. 2008, 25, 384-396. [CrossRef]

38. Raida, M.K.; Buchmann, K. Bath vaccination of rainbow trout (Oncorhynchus mykiss Walbaum) against Yersinia ruckeri: Effects of temperature on protection and gene expression. Vaccine 2008, 26, 1050-1062. [CrossRef]

39. Takeda, K.; Kaisho, T.; Akira, S. Toll-Like receptors. Annu. Rev. Immunol. 2003, 2, 335-376. [CrossRef]

40. Hayashi, F.; Smith, K.D.; Ozinsky, A.; Hawn, T.R.; Yi, E.C.; Goodlett, D.R.; Eng, J.K.; Akira, S.; Underhill, D.M.; Aderem, A. The innate immune response to bacterial flagellin is mediated by Toll-like receptor 5 . Nature 2001, 410, 1099-1103. [CrossRef] 
41. Iqbal, M.; Philbin, V.J.; Withanage, G.S.K.; Wigley, P.; Beal, R.K.; Goodchild, M.J.; Barrow, P.; McConnell, I.; Maskell, D.J.; Young, J.; et al. Identification and functional characterization of chicken toll-like receptor 5 reveals a fundamental role in the biology of infection with Salmonella enterica serovar typhimurium. Infect. Immun. 2005, 73, 2344-2350. [CrossRef] [PubMed]

42. Stockhammer, O.W.; Zakrzewska, A.; Hegedûs, Z.; Spaink, H.P.; Meijer, A.H. Transcriptome profiling and functional analyses of the zebrafish embryonic innate immune response to Salmonella infection. J. Immunol. 2009, 182, 5641-5653. [CrossRef] [PubMed]

43. Yoon, S.I.; Kurnasov, O.; Natarajan, V.; Hong, M.; Gudkov, A.V.; Osterman, A.L.; Wilson, I.A. Structural basis of TLR5-flagellin recognition and signaling. Science 2012, 335, 859-864. [CrossRef] [PubMed]

44. Akira, S.; Takeda, K. Functions of toll-like receptors: Lessons from KO mice. C. R. Biol. 2004, 327, 581-589. [CrossRef]

45. Van der Vaart, M.; van Soest, J.J.; Spaink, H.P.; Meijer, A.H. Functional analysis of a zebrafish myd88 mutant identifies key transcriptional components of the innate immune system. Dis. Model. Mech. 2013, 6, 841-854. [CrossRef]

46. Fullard, N.; Wilson, C.L.; Oakley, F. Roles of c-Rel signalling in inflammation and disease. Int. J. Biochem. Cell. Biol. 2012, 44, 851-860. [CrossRef]

47. Zheng, X.; Dai, W.; Chen, X.; Wang, K.; Zhang, W.; Liu, L.; Hou, J. Caffeine reduces hepatic lipid accumulation through regulation of lipogenesis and ER stress in zebrafish larvae. J. Biomed. Sci. 2015, 22, 1-12. [CrossRef]

48. Rojo, I.; de Ilárduya, Ó.M.; Estonba, A.; Pardo, M.Á. Innate immune gene expression in individual zebrafish after Listonella anguillarum inoculation. Fish Shellfish Immunol. 2007, 23, 1285-1293. [CrossRef]

49. Bhatt, P.; Kumaresan, V.; Palanisamy, R.; Ravichandran, G.; Mala, K.; Amin, S.M.N.; Arshad, A.; Yusoff, F.M.; Arockiaraj, J. A mini review on immune role of chemokines and its receptors in snakehead murrel Channa striatus. Fish Shellfish Immunol. 2018, 72, 670-678. [CrossRef]

50. Cobo, E.R.; Kissoon-Singh, V.; Moreau, F.; Chadee, K. Colonic MUC2 mucin regulates the expression and antimicrobial activity of $\beta$-defensin 2. Mucosal Immunol. 2015, 8, 1360-1372. [CrossRef]

51. Milton, J.S. Heat Shock Proteins. J. Biol. Chem. 1990, 25, 1211-1214. [CrossRef]

52. Gunderson, L.L.; Tepper, J.E. Clinical Radiation Oncology, 4th ed.; Elsevier Health Sciences: Philadelphia, PA, USA, 2015.

53. Kono, T.; Sakai, M. The analysis of expressed genes in the kidney of Japanese flounder, Paralichthys olivaceus, injected with the immunostimulant peptidoglycan. Fish Shellfish Immunol. 2001, 11, 357-366. [CrossRef] [PubMed]

54. Kawai, T.; Akira, S. The role of pattern-recognition receptors in innate immunity: Update on toll-like receptors. Nat. Immunol. 2010, 11, 373-384. [CrossRef] [PubMed]

55. Heo, S.J.; Yoon, W.J.; Kim, K.N.; Ahn, G.N.; Kang, S.M.; Kang, D.H.; Affan, A.; Oh, C.; Jung, W.K.; Jeon, Y.J. Evaluation of anti-inflammatory effect of fucoxanthin isolated from brown algae in lipopolysaccharide-stimulated RAW 264.7 macrophages. Food Chem. Toxicol. 2010, 48, 2045-2051. [CrossRef] [PubMed]

56. Grayfer, L.; Hodgkinson, J.W.; Hitchen, S.J.; Belosevic, M. Characterization and functional analysis of goldfish (Carassius auratus L.) interleukin-10. Mol. Immunol. 2011, 48, 563-571. [CrossRef] [PubMed]

57. Chandrarathna, H.P.S.U.; Nikapitiya, C.; Dananjaya, S.H.S.; Wijerathne, C.U.B.; Wimalasena, S.H.M.P.; Kwun, H.J.; Heo, G.J.; Lee, J.; De Zoysa, M. Outcome of co-infection with opportunistic and multidrug resistant Aeromonas hydrophila and $A$. veronii in zebrafish: Identification, characterization, pathogenicity and immune responses. Fish Shellfish Immunol. 2018, 80, 573-581. [CrossRef]

58. Livak, K.J.; Schmittgen, T.D. Analysis of relative gene expression data using real-time quantitative PCR and the $2^{-\Delta \Delta C T}$ Method. Methods 2001, 25, 402-408. [CrossRef]

(C) 2020 by the authors. Licensee MDPI, Basel, Switzerland. This article is an open access article distributed under the terms and conditions of the Creative Commons Attribution (CC BY) license (http://creativecommons.org/licenses/by/4.0/). 